\title{
E-Learning System Use During Emergency: An Empirical Study During the COVID-19 Pandemic
}

\author{
Ibrahim Alyoussef* \\ Faculty of Education, Education Technology Department, King Faisal University, Alahsa, Saudi Arabia
}

OPEN ACCESS

Edited by:

Ana B. Bernardo,

University of Oviedo, Spain

Reviewed by:

María Esteban,

University of Oviedo, Spain

Christina Andersson,

Frankfurt University of Applied

Sciences, Germany

Quoc Trung Pham,

Ho Chi Minh City University of

Technology, Vietnam

*Correspondence:

Ibrahim Alyoussef

ialyoussef@kfu.edu.sa

Specialty section:

This article was submitted to

Higher Education,

a section of the journal

Frontiers in Education

Received: 08 March 2021

Accepted: 12 May 2021

Published: 07 June 2021

Citation:

Alyoussef I (2021) E-Learning System Use During Emergency: An Empirical

Study During the COVID-

19 Pandemic.

Front. Educ. 6:677753.

doi: 10.3389/feduc.2021.677753
The pandemic of COVID-19 quickly led to the closure of universities and colleges around the world, hoping that the guidance of social distancing from public health authorities will help flatten the curve of infection and minimize the overall fatalities from the epidemic. The e-learning framework, however, is the best solution to enable students to learn about the quality of education. The aim of this research was to examine variables reflecting the actual use of the e-learning system during the COVID-19 pandemic among university students. The perceived ease of use and perceived usefulness are positively correlated with facilitating condition, perceived control, and self-efficacy, which in turn influences students' attitude toward use, which in turn affects the actual use of the e-learning system during the COVID-19 pandemic. To exam the model on the basis of user data from the e-learning system used collected through an online survey, structural equation modeling (SEM) and path analysis were used. The findings showed that the mindset of students to use had positive effects on the learning of students during the COVID-19 pandemic through the actual use of the e-learning system. In the context of e-learning programs in developing countries, previous studies have seldom explored an integrated model. In addition, this article aims to include a literature review of recently published research on the actual use of the e-learning system during the pandemic of COVID-19.

Keywords: e-learning system, COVID-19 pandemic, TAM, students' learning, higher education

\section{INTRODUCTION}

The corona virus disease 2019 (COVID-19) pandemic has been severely damaging. The World Health Organization, WHO (World Health Organization, 2020), when this article was written, registered almost 95.5 million cases. The COVID-19 pandemic has produced changes in the teaching-learning environment in higher education institutions and has impacted learning between teachers and students. As a result of the pandemic, universities were reduced to performing their operations primarily online with students (Sobaih et al., 2020).The COVID-19 pandemic gradually evolved from its first introduction into a genuinely global phenomenon. While the social dissemination of the virus is of significance for the securitization of face-to-face schooling, the perspective is provided by a brief overview of the growth of the virus. The first reported disease onset date of COVID-19 was December 1, 2019, and the first hospital intake date was December 16, 2019 (Huang et al., 2020). A cluster of patients with pneumonia in Wuhan, China, was reported at the World Health Organization's Beijing office on December 30, 2019 (Guarner, 2020). In clinical presentations, a shared viral pneumonia strain, called COVID-19 or 2019 novel coronavirus, was indicated (Huang et al., 2020). An epidemiological warning was posted by the health authorities the next day (Huang et al., 2020). About a month after the 
viral pneumonia cluster was recognized, just under two months after the first symptoms ever caused by the virus (Lai et al., 2020), and on March 11, 2020, the COVID-19 pandemic (WHO coronavirus Disease (COVID-19) dashboard, 2020), the World Health Organization declared a Global Health Emergency of International Importance. The severity of the virus has been very catastrophic; the closing of colleges and schools was one of the effects during the COVID-19 pandemic. There is also an inescapable need to use technology in education for educational purposes during the pandemic; a number of recent reports have raised this issue (Almanthari et al., 2020; Kerres, 2020; Wang et al., 2020). One of the technologies used during COVID-19 is e-learning, a media integration for teaching that uses a consolidated platform to organize communication processes during instructional activities. Innovative networks of technology, such as Edmodo, social media, forum, Coursera, or special higher education platforms, apply computer-managed e-learning to immersive online learning. By the use of the e-learning system (Omar et al., 2011; Al-Rahmi et al., 2020a), students are expected to make meaningful progress in doing their learning activities. Two considerations are frequently used to construct e-learning in higher education, namely, manageable costs and support facilities to promote learning effects (Clark and Mayer, 2016). The purpose of the implementation of the e-learning method in normal circumstances is to promote more flexible, usable, and efficient face-to-face learning (Al-Rahmi et al., 2020b). In the plethora studies (Megahed and Mohammed, 2020; Shi et al., 2020), the use of the e-learning system as a research object was discussed. Some recent studies have also been reported during COVID-19 (Almanthari et al., 2020; Abbasi et al., 2020; Favale et al., 2020; Radha et al., 2020) on e-learning system applications in education. However, research on the adoption of the e-learning system is still limited in developed countries and, in particular, on topic matters. This thesis was therefore conducted to understand variables predicting the eventual use of the e-learning method through path analysis by university students. Universities and school doors were closed to restrict the dissemination of COVID-19. More than 1.7 billion students around the world have been affected by the closure, according to the report, with 160 countries implementing the closure because of the pandemic (UNESCO, 2020). It can be estimated that COVID-19 has affected 91 percent or more of the global student population. The recession has opened up an incentive for both the application of technology and the challenges it faces at about the same time. On the other hand, the role of technology in changing the learning process, fostering sustainable teaching, and facilitating distance learning education for students around the world has produced enormous perspectives (Abbasi et al., 2020). Therefore, this research develops a new model of the e-learning system use during the COVID-19 pandemic.

\section{THEORETICAL BACKGROUND AND HYPOTHESES DEVELOPMENT}

This study was developed based on methods of technology adoption "e-learning system" that are used to analyze students' attitude on the application and intent of behavior during the COVID-19 pandemic to influence the use of the e-learning method. Thus, the study developed 12 hypotheses and the results from it developed a new model shown in Figure 1. Also, in this research, technology acceptance model (TAM) has been applied as a highly promising way to measure students' attitudes and behaviors toward using computer technology (Vankatesh and Davis, 1996). The perception of ease of use, usefulness, and attitude of students to use by students has been noticed by several researchers (Islam, 2013; Al-Rahmi et al., 2019a). Liaw and Huang (2014) and Al-Rahmi et al. (2018a) found that the attitude of learners to technologies, like the e-learning system, had a major positive influence on the self-efficacy of learners. The current research, followed by a synthesis of the main theories and previous similar studies, starts by evaluating the current literature on technology adoption. A model of the core structures of the practical use of e-learning systems as the result of this study. Moreover, this study filled the research gap to develop a new model through seven main factors shown in sections from Facilitating Condition to Actual Use of the E-Learning System During COVID-19 Pandemic. To understand the schooling of learners during the COVID-19 pandemic by the use of the e-learning system, an extended technology adoption model is used. Believed that the stimuli experienced in the e-learning system's environment can be called external environment stimuli and are related to the mental reaction provided by learning self-efficacy (Illeris, 2003), and here the internal psychological process is divided into selfefficacy. The research model variables are as follows: independent influences: facilitating condition (FC), perceived control (PC), selfefficacy (SE), and mediator factors are perceived as perceived ease of usage (PEU), perceived usefulness (PU), and attitude of students toward use (AT) during the COVID-19 pandemic, which in turn affects the dependent factors of actual use of the e-learning system (AUE). Refer Figure 1.

\section{Facilitating Condition}

The facilitating condition is introduced to become the only external variable that accompanies the main TAM-based build. It is described as the degree to which students believe that the use of the COVID-19 pandemic e-learning platform has organizational and technological resources to support it. It is believed that conditioned facilitation is correlated with perceived ease of use and perceived usefulness. Previously, facilitating conditions have been reported to substantially predict perceived ease of use for the implementation of educational technology (Nikou and Economides, 2017; Muhaimin et al., 2019). In addition, it was also stated to have been significantly related to perceived usefulness (Rahimi et al., 2015). Nonetheless, two previous studies (Muhaimin et al., 2019; Teo et al., 2019) have stated that condition facilitating is an irrelevant measure of perceived utility. The following theories were suggested based on the discussion above:

$\mathrm{H} 1$ : FC is positively associated with PEU.

$\mathrm{H} 2$ : FC is positively associated with PU.

\section{Perceived Control}

Teaching classroom control is also defined as a single dimension that ranges from teacher control to student autonomy and also 


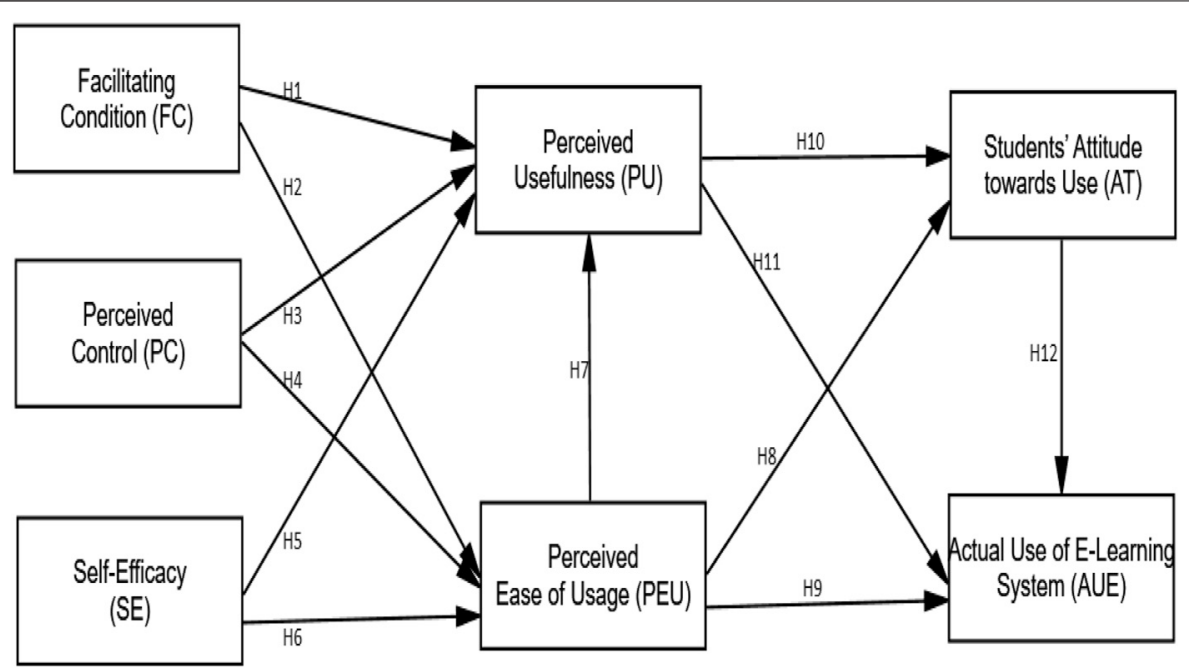

FIGURE 1 | Research model and hypothesis.

teacher and student learning control (DeCharms, 1976). Classroom management depends on the quality and direction of instruction, as managed by instructors, and the opportunities for self-directed learning for the students (Bandura and Wood, 1989). Connell (1985) believes that by providing options for choice and self-directed learning to students, perceived autonomy can be improved. Decades of study has found that perceived influence is correlated with motivation and different measures of satisfaction, such as the relationship between parent and child (Abad and Sheldon, 2008) and friendship (Demir et al., 2013). This description has also been extended to the relationship between teacher and student: the perceived control of students has been shown to increase the internal understanding of learning (Bonneville-Roussy et al., 2013; Simon et al., 2015), suggesting that control is perceived to be affected by the use of the e-learning system during the COVID-19 pandemic. The following theories were suggested based on the discussion above:

H3: PC is positively associated with PEU.

$\mathrm{H} 4$ : PC is positively associated with PU.

\section{Self-Efficacy}

Self-efficacy refers to a learner's trust that he or she can achieve a mission and accomplish a goal (Bandura, 1977; Bandura, 1986). Generative ability in which cognitive, social, and behavioral subskills must be structured into integrated action courses to fulfill the generative capacity of countless reasons to organize cognitive, social, and behavioral subskills into integrated action courses to serve countless purposes. For Liaw and Huang, selfefficacy is a beneficial feature of successful learning (Liaw and Huang, 2013). Therefore, a high degree of perceived self-efficacy leads to improved learning performance and greater behavioral retention in e-learning environment settings (Chu and Chu, 2010; Liaw and Huang, 2013). Therefore, learners' self-efficacy determines their useful learning, attitudes, skills development, choice of activities, and continuing encouragement to learn through the actual use of the e-learning system during the COVID-19 pandemic. The following theories were suggested based on the discussion above:

H5: SE is positively associated with PEU.

H6: SE is positively associated with PU.

\section{Perceived Ease of Use}

As one of the main variables of the original TAM, the perceived ease of use is defined as the degree to which learners believe that during COVID-19 it will be easy to use the e-learning system. Perceived ease of use is characterized as the degree to which a person assumes that using a system (Davis, 1989), which is an imminent adoption factor of modern technology-based applications, would be effortless (Venkatesh, 2000). In several previous research studies (Chen and Tseng, 2012; Islam, 2013; Al-rahmi et al., 2015a; Al-Maatouk et al., 2020), the effect of perceived ease of use on the intent to use the e-learning system has been shown. Therefore, the more ambitious the aim of using the e-learning system is, the greater the perceived ease of use of the e-learning system; thus, the greater the likelihood of using it. Moreover, in the sense of the e-learning system, perceived ease of use is often believed to have an indirect effect on the attitude of use perceived by usefulness (Chen and Tseng, 2012). Therefore, the perceived ease of use is also predicted to have an indirect influence on users' perceptions by the perceived usefulness of the use of the e-learning system during the COVID-19 pandemic. Based on the above discussion, following hypotheses were proposed:

H7: PEU is positively associated with PU.

H8: PEU is positively associated with AT.

H9: PEU is positively associated with AUE.

\section{Perceived Usefulness}

The perceived usefulness has been accepted as the student level believes that during COVID-19, the use of the e-learning system would increase the performance. A primary determinant of 
purpose is perceived usefulness, which stimulates IS consumers to implement more innovative and user-friendly technologies in the 21st century that give them greater freedom (Pikkarainen et al., 2004; Abuhassna et al., 2020). It was found that perceived usefulness had a significant positive effect on the decision to use the e-learning system's resources (Chen and Tseng, 2012; Cheng, 2012; Islam, 2013; Al-Rahmi et al., 2019b). Therefore, the higher the perceived usefulness of the actual e-learning system, the more positive the attitude to use it is; thus, after the COVID19 pandemic, the greater the probability of using the e-learning system. Based on the above discussion, following hypotheses were proposed:

H10: PU is positively associated with AT.

H11: PU is positively associated with AUE.

\section{Students' Attitude to Use}

The attitude in this study is represented as some students' behavior is associated with the use of the e-learning system during COVID-19. The attitude was hypothesized to have a strong correlation with behavioral intent. (Mohammadi (2015) and Al-Rahmi et al. (2020b) found that if the extent of such behavior correlated with the use of technology was higher, the attitude toward using technology would also be more significant. Based on the TAM, behavioral intent, which is described as the attitude of students to use the e-learning framework during COVID-19, was included. It is expected that the behavioral attitude in this analysis would have a statistically significant relationship with the actual use of the e-learning system during COVID-19. Previous experiments have demonstrated that students' behavior and attitudes are closely related to the actual use of technology, in general the e-learning system (Teo, 2009; Ramírez-Correa et al., 2015), hence the attitude of students to use the e-learning system during the COVID-19 pandemic. Based on the above discussion, the following hypothesis was proposed:

H12: AT is positively associated with AUE.

\section{Actual Use of the E-Learning System During COVID-19 Pandemic}

The higher education system is currently in a constant transformation phase, with universities having to keep pace with the demands and expectations of students. Accordingly, information technology and e-learning platforms are key factors in the implementation of the activities of universities, which are increasingly investing in online systems and devices (Popovici and Mironov, 2015; Alalwan et al., 2019). One of the key challenges for universities in the technology age, however, is the integration of an advanced e-learning framework to improve and sustain both teaching and learning (Fischer et al., 2014; AlRahmi et al., 2018b). The e-learning framework has several features that promote and cultivate the learning-teaching process, providing a broad range of options for exchanging information and uploading documents in various formats. The installation of additional tools is not needed because it is a web- based framework, and once published, the content is accessible to users at any time (Raheem and Khan, 2020; Alamri et al., 2020). The effect of the pandemic on education, universities, teachers, and students has become a topic of great concern to researchers because of the extraordinary situation produced by the COVID19 pandemic. Examining the opinion of students regarding online learning during the COVID-19 pandemic, Allo found that students had a positive attitude about the use of the e-learning system, finding it beneficial and useful during the time of the pandemic crisis (Allo, 2020).

\section{RESEARCH METHODOLOGY}

This research was performed by an online survey from October 2020 to December 2020, when universities were closed from March 2020. A survey instrument to measure factors predicting the use of the e-learning method during COVID-19 among students was developed and validated prior to the main data collection. Of the 371 questionnaire participants, 363 returned responses. However, another nine participants' responses were eliminated from analysis since they were incomplete. Confirmatory factor analysis was used to ensure the model's validity. Partial least square structural equation modeling (PLSSEM) was employed using SmartPLS 2.0.

\section{Data Collection and Sampling Method}

Using the questionnaires as a data collection tool, a quantitative research model was adopted for this research. The primary statistical analysis method was PLS-SEM, with SPSS software used for data analysis; in this research, the sample size for the analysis was determined using Roscoe's rule of thumb (Sekaran and Bougie, 2016).Also, according to Taherdoost (2016), sampling can be used to build a model about a population or to make generalizations based on existing theory. In general, there are two kinds of sampling techniques: probability or normal sampling and non-probability or nonrandom sampling. It is necessary to decide on a large sampling technique before deciding on a particular form of sampling technique. Therefore, the sampling method for this research was probability or random sampling, and it was recommended by Taherdoost, (2016). As a result, multiplying 10 by 25 items provided a sufficient sample size of 250 participants for this study. Thus, 354 participants were imported into the SPSS package software. Postgraduate and undergraduate students at university, who are active users of the e-learning system during the COVID-19 pandemic, were the sample of this research. A sufficient degree of reliability was determined through computing composite reliability. Initially, constructs validity was performed in two steps by calculating first convergent validity and second by assessing discriminant validity. Convergent validity was determined to evaluate the model's fit appropriateness before assessing the hypotheses by three procedures: factor loadings, average variance extracted AVE, and composite reliability. As detailed in section four, discriminant validity was assessed through the criterion test, in accordance with Hair et al. (2019). The structural model was assessed in the second stage. 


\section{Instrument Measurement}

Regarding the data collection technique, the instrument was adopted from within the extant research and the principal research was used. A five-point Likert scale was adopted for the questionnaire items, with " 5 " indicating strong agreement and " 1 " indicating strong disagreement by the respondent. The inaccuracy in the outcomes may result from some exceptional cases, the data analysis to come in accordance with Hair et al. (2019). The questionnaire used in this research was adopted from the previous research facilitating condition that adapted three items from Habibi et al. (2020), perceived control adapted three items from Eshel (1991), self-efficacy adapted four items from Abdullah et al. (2016), perceived ease of use adapted four items from Davis (1989), perceived usefulness adapted four items from Davis (1989), students' attitude towards use adapted four items from Ratna and Mehra, (2015), and actual use of e-learning system during COVID-19 pandemic adapted three items from Peral et al. (2014); Ratna and Mehra, (2015).

\section{RESULTS AND ANALYSIS}

Demographic variables were classified according to gender, age, level of education, and specialization. With regard to gender, 195 (55.1\%) were male and 159 (44.9\%) were female, 209 (59\%) were in the $18-21$ age group, $76(21.5 \%)$ were in the $22-25$ age range, and $69(19.5 \%)$ were in the 26-29 age group. The level of education was $269(76.0 \%)$ undergraduate students and 85 $(24.0 \%)$ postgraduate students. $101(28.5 \%)$ of respondents were from social science, $77(21.8 \%)$ of respondents were from engineering, and 176 (49.7\%) of respondents were from science and technology, in contrast to the demographic variables of specialization. Cronbach's a reliability coefficient value for all constructs (facilitating condition, perceived control, self-efficacy, perceived ease of use, perceived usefulness, students' attitude toward use, and the actual use of the e-learning system use during the COVID-19 pandemic) was 0.827. Discriminant validity (DV) is considered satisfactory when 1) the index of factors is less than 0.80 (Hair et al., 2019), 2) the average extracted variance (AVE) value of each construct is equal to or greater than 0.50 , and 3 ) and the square root value of AVE of each construct is greater than the inter-construct correlations (IC) connected with the factor (Hair et al., 2019). Moreover, crematory factor analysis (CFA) with factor loading (FL) values must be about the minimal acceptable level of 0.70 , whereas the values of Cronbach's a (CA) ought to be equal to or above 0.70 (Hair et al., 2019). Durability of composite (CR) was also taken into consideration and it should be equal to 0.70 .

\section{Measurement Model Fit and Instrumentation}

The first stage needed to confirm the validity of this model is to employ the partial least square structural equation modeling (PLS-SEM) Smart PLS 2.0. Prior to testing the hypotheses, the reliability of this model was confirmed in two steps. The CMN/ DF ratio was 2.407 , which was below the threshold (5.00). TLI
(0.962) and IFI (0.951) are exceptional, GFI (0.927) is a good standard, and CFI (0.955) is outstanding. RMR and RMSEA of $0.33(0.05)$ and $0.034(0.08)$, respectively, were smaller than the cutoff (Hair et al., 2019), indicating that the model's badness metrics were adequate.

\section{Construct Validity of Measurements}

Construct validity is defined as the degree to which a test measures everything it needs to be measuring. Construct validity, content validity, and criterion validity are the three principal types of validate evidence (Hair et al., 2019). Factor analysis showed that factors had high loading and cross-loading of items (Table 1).

\section{Convergent Validity of the Measurement Model}

The composite reliability scores ranged from 0.932650 to 0.871728 . These scores are above the required threshold of 0.70 proving that all constructs can be considered. Furthermore, Cronbach's a values varied from 0.903448 to 0.819590 . This also satisfies the condition of being higher than 0.60 . At the same time, the average variance extracted (AVE) values ranged from 0.792393 to 0.679315 surpassing the minimal limit of 0.50 , while critical element loadings surpassed 0.50 (Hair et al., 2019), see Table 2.

\section{Discriminant Validity of the Measurement Model}

Discriminant validity is the extent that differentiates a latent variable from other latent variables. Discriminant validity is when a latent variable can explain more variance in the observed variables connected to it than a) measurement error or similar exterior unmeasured effects or b) other constructs within the conceptual framework. Should this be not the case, then the validity of each one of the indicators and of the construct becomes unreliable (Hair et al., 2019), see Table 3.

\section{Structural Model Analysis}

The path modeling research in the current study was used to construct a model to measure facilitating conditions, perceived control, and self-efficacy with TAM model variables on the actual use of the e-learning system during the pandemic of COVID-19. The effects are shown and compared in the hypothesis testing discussion, according to the model. Subsequently, factor analysis (CFA) was conducted on SEM to evaluate the suggested hypotheses as seen in the path model results in Figure 2 and hypotheses testing in Figure 3 for the second step.

Figure 2 and Figure 3 above indicate that the findings of this research have accepted all hypotheses via path model results and hypotheses testing. In addition, Table 4 below indicates that the key model statistics were fit, demonstrating model validity and hypotheses by showing the values of standard errors and then unstandardized coefficients of structural model testing coefficients. 
TABLE 1 | Factor analysis and cross-loading values.

\begin{tabular}{|c|c|c|c|c|c|c|c|c|}
\hline Factor & Item & At & PC & FC & SE & PEU & PU & EU \\
\hline \multirow[t]{4}{*}{ Attitude to use } & AT1 & 0.86 & 0.39 & 0.46 & 0.47 & 0.43 & 0.44 & 0.46 \\
\hline & AT2 & 0.87 & 0.35 & 0.38 & 0.43 & 0.42 & 0.43 & 0.45 \\
\hline & AT3 & 0.74 & 0.34 & 0.31 & 0.42 & 0.42 & 0.42 & 0.34 \\
\hline & AT4 & 0.85 & 0.36 & 0.38 & 0.46 & 0.50 & 0.52 & 0.50 \\
\hline \multirow[t]{3}{*}{ Perceived control } & PC1 & 0.39 & 0.82 & 0.54 & 0.39 & 0.36 & 0.34 & 0.38 \\
\hline & PC2 & 0.37 & 0.87 & 0.46 & 0.34 & 0.37 & 0.31 & 0.36 \\
\hline & PC3 & 0.31 & 0.81 & 0.39 & 0.30 & 0.33 & 0.28 & 0.33 \\
\hline \multirow[t]{3}{*}{ Facilitating condition } & FC1 & 0.40 & 0.51 & 0.88 & 0.35 & 0.37 & 0.33 & 0.39 \\
\hline & FC2 & 0.40 & 0.48 & 0.91 & 0.35 & 0.37 & 0.36 & 0.40 \\
\hline & FC3 & 0.43 & 0.51 & 0.89 & 0.37 & 0.38 & 0.35 & 0.40 \\
\hline \multirow[t]{4}{*}{ Self-efficacy } & SE1 & 0.47 & 0.35 & 0.35 & 0.83 & 0.47 & 0.43 & 0.47 \\
\hline & SE2 & 0.41 & 0.30 & 0.28 & 0.83 & 0.39 & 0.36 & 0.40 \\
\hline & SE3 & 0.40 & 0.35 & 0.35 & 0.83 & 0.42 & 0.40 & 0.41 \\
\hline & SE4 & 0.48 & 0.36 & 0.33 & 0.82 & 0.48 & 0.45 & 0.48 \\
\hline \multirow[t]{4}{*}{ Perceived ease of use } & PEU1 & 0.48 & 0.35 & 0.33 & 0.44 & 0.82 & 0.67 & 0.47 \\
\hline & PEU2 & 0.38 & 0.32 & 0.31 & 0.40 & 0.80 & 0.54 & 0.45 \\
\hline & PEU3 & 0.44 & 0.37 & 0.36 & 0.46 & 0.84 & 0.58 & 0.50 \\
\hline & PEU4 & 0.44 & 0.36 & 0.38 & 0.46 & 0.84 & 0.61 & 0.46 \\
\hline \multirow[t]{4}{*}{ Perceived usefulness } & PU1 & 0.50 & 0.36 & 0.38 & 0.43 & 0.65 & 0.89 & 0.49 \\
\hline & PU2 & 0.47 & 0.32 & 0.34 & 0.44 & 0.65 & 0.91 & 0.51 \\
\hline & PU3 & 0.49 & 0.34 & 0.36 & 0.46 & 0.64 & 0.89 & 0.48 \\
\hline & PU4 & 0.45 & 0.29 & 0.28 & 0.42 & 0.63 & 0.83 & 0.46 \\
\hline \multirow[t]{3}{*}{ E-learning system use during COVID-19 } & EU1 & 0.42 & 0.33 & 0.34 & 0.46 & 0.46 & 0.46 & 0.85 \\
\hline & EU2 & 0.48 & 0.37 & 0.38 & 0.48 & 0.50 & 0.49 & 0.88 \\
\hline & EU3 & 0.47 & 0.41 & 0.41 & 0.42 & 0.51 & 0.46 & 0.84 \\
\hline
\end{tabular}

TABLE 2 | Crematory factor analysis of the measurement model.

\begin{tabular}{|c|c|c|c|c|c|c|}
\hline Factor & Item & Factor loading & AVE & $\begin{array}{c}\text { Composite } \\
\text { reliability }\end{array}$ & $\mathbf{R}$ square & Cronbach's alpha \\
\hline \multirow[t]{4}{*}{ Attitude to use } & AT1 & 0.86 & 0.693861 & 0.900314 & 0.333603 & 0.851917 \\
\hline & AT2 & 0.87 & & & & \\
\hline & AT3 & 0.74 & & & & \\
\hline & AT4 & 0.85 & & & & \\
\hline \multirow[t]{3}{*}{ Perceived control } & PC1 & 0.82 & 0.693998 & 0.871728 & 0.000000 & 0.879409 \\
\hline & PC2 & 0.87 & & & & \\
\hline & PC3 & 0.81 & & & & \\
\hline \multirow[t]{3}{*}{ Facilitating condition } & FC1 & 0.88 & 0.792393 & 0.919668 & 0.000000 & $0.868,910$ \\
\hline & FC2 & 0.91 & & & & \\
\hline & FC3 & 0.89 & & & & \\
\hline \multirow[t]{4}{*}{ Self-efficacy } & SE1 & 0.83 & 0.687028 & 0.897756 & 0.000000 & 0.848607 \\
\hline & SE2 & 0.83 & & & & \\
\hline & SE3 & 0.83 & & & & \\
\hline & SE4 & 0.82 & & & & \\
\hline \multirow[t]{4}{*}{ Perceived ease of use } & PEU1 & 0.82 & 0.679315 & 0.894398 & 0.446654 & 0.842692 \\
\hline & PEU2 & 0.80 & & & & \\
\hline & PEU3 & 0.84 & & & & \\
\hline & PEU4 & 0.84 & & & & \\
\hline \multirow[t]{4}{*}{ Perceived usefulness } & PU1 & 0.89 & 0.776058 & 0.932650 & 0.593006 & 0.903448 \\
\hline & PU2 & 0.91 & & & & \\
\hline & PU3 & 0.89 & & & & \\
\hline & PU4 & 0.83 & & & & \\
\hline \multirow[t]{3}{*}{ E-learning system use during COVID-19 } & EU1 & 0.85 & 0.735211 & 0.892764 & 0.420562 & 0.819590 \\
\hline & EU2 & 0.88 & & & & \\
\hline & EU3 & 0.84 & & & & \\
\hline
\end{tabular}

As shown in Table 4, all hypotheses were accepted as all the seven factors were found to be statistically significant. There is a relationship between facilitating condition and perceived ease of use $(\mathrm{H} 1)(\beta=0.054809$ and $t=2.505118)$ : the result of this research confirmed that hypothesis is positively supported by the facilitating condition that makes the e-learning system ease of use. 
TABLE 3 | Discriminant validity of the measurement model.

\begin{tabular}{|c|c|c|c|c|c|c|c|c|}
\hline Factor & Item & At & EU & FC & $\mathrm{PC}$ & PEU & PU & SE \\
\hline Attitude toward use & AT & 1.00 & & & & & & \\
\hline E-learning system during COVID-19 & EU & 0.53 & 1.00 & & & & & \\
\hline Facilitating condition & $\mathrm{FC}$ & 0.46 & 0.44 & 1.00 & & & & \\
\hline Perceived control & $\mathrm{PC}$ & 0.43 & 0.43 & 0.56 & 1.00 & & & \\
\hline Perceived ease of use & PEU & 0.53 & 0.57 & 0.42 & 0.42 & 1.00 & & \\
\hline Perceived usefulness & PU & 0.54 & 0.55 & 0.39 & 0.37 & 0.73 & 1.00 & \\
\hline Self-efficacy & SE & 0.53 & 0.53 & 0.40 & 0.41 & 0.53 & 0.50 & 1.00 \\
\hline
\end{tabular}

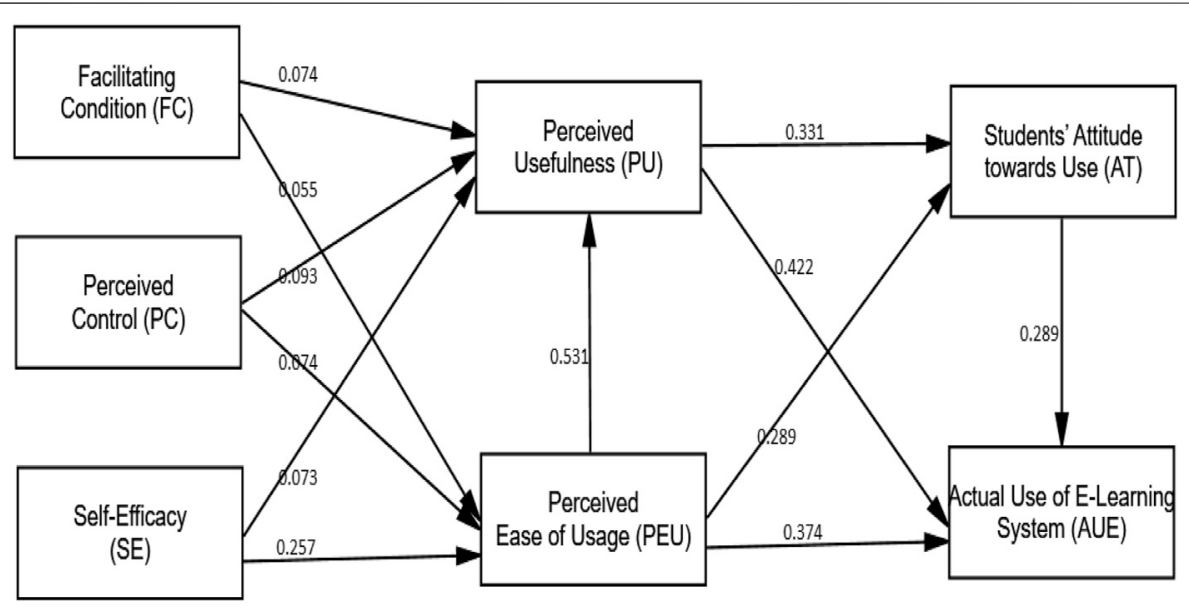

FIGURE 2 | Path coefficients results.

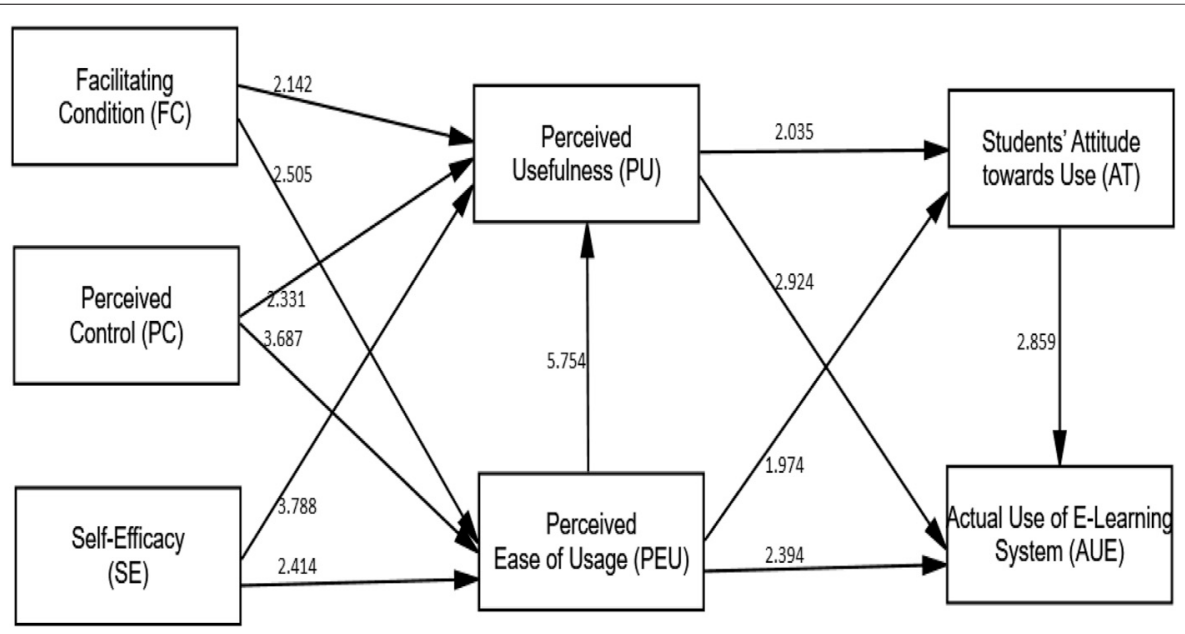

FIGURE 3 | Hypothesis testing.

Similarly, there is a relationship between facilitating condition and perceived usefulness $(\mathrm{H} 2)(\beta=0.074292$ and $\mathrm{t}=2.142176)$ : the result of this research confirmed that the hypothesis is positively supported by the facilitating condition that makes the e-learning system useful. Second, there is a relationship between perceived control and perceived ease of use $(\mathrm{H} 3)(\beta=$
0.074433 and $t=3.687396)$ : the result of this research confirmed that the hypothesis is positively supported by perceived control that makes the e-learning system ease of use, and also there is a relationship between perceived control and perceived usefulness (H4) $(\beta=0.093211$ and $t=2.331149)$ : the result of this research confirmed that the hypothesis is positively supported through 
TABLE 4 | Hypotheses testing.

\begin{tabular}{|c|c|c|c|c|c|}
\hline $\begin{array}{l}\text { Hypothesis } \\
\text { relationship }\end{array}$ & Path coefficient & Standard deviation & Standard error & $\begin{array}{c}\text { T statistics } \\
\text { (T.value) }\end{array}$ & Result \\
\hline Facilitating condition and perceived ease of use $(\mathrm{H} 1)$ & 0.054809 & $0.108,507$ & $0.108,507$ & 2.505118 & Supported \\
\hline Facilitating condition and perceived usefulness $(\mathrm{H} 2)$ & 0.074292 & 0.089911 & 0.089911 & 2.142176 & Supported \\
\hline Perceived control and perceived ease of use $(H 3)$ & 0.074433 & 0.108283 & 0.108283 & 3.687396 & Supported \\
\hline Perceived control and perceived usefulness $(\mathrm{H} 4)$ & 0.093211 & 0.097270 & 0.097270 & 2.331149 & Supported \\
\hline Self-efficacy and perceived ease of use (H5) & 0.256649 & 0.106334 & 0.106334 & 2.413613 & Supported \\
\hline Self-efficacy and perceived usefulness $(\mathrm{H} 6)$ & 0.073766 & 0.093665 & 0.093665 & 3.787546 & Supported \\
\hline Perceived ease of use and perceived usefulness $(\mathrm{H} 7)$ & $0.530,577$ & 0.092214 & 0.092214 & 5.753757 & Supported \\
\hline Perceived ease of use and attitude toward use $(\mathrm{H} 8)$ & 0.289979 & 0.146919 & 0.146919 & 1.973729 & Supported \\
\hline Perceived ease of use and actual use of e-learning (H9) & 0.374401 & 0.123469 & 0.092101 & 2.393632 & Supported \\
\hline Perceived usefulness and attitude toward use $(\mathrm{H} 10)$ & 0.330564 & 0.162412 & 0.162412 & 2.035344 & Supported \\
\hline Perceived usefulness and actual use of e-learning $(\mathrm{H} 11)$ & 0.422371 & 0.326935 & 0.083492 & 2.923845 & Supported \\
\hline Attitude toward use and actual use of e-learning (H12) & 0.288759 & 0.101002 & 0.101002 & 2.858943 & Supported \\
\hline
\end{tabular}

perceived control that makes the e-learning system useful. Third, there is a relationship between self-efficacy and perceived ease of use (H5) $(\beta=0.256649$ and $t=2.413613)$ : the result of this research confirmed that the hypothesis is positively supported by self-efficacy that makes the e-learning system ease of use. Likewise, there is a relationship between self-efficacy and perceived usefulness (H6) $(\beta=$ 0.073766 and $t=3.787546)$ : the result of this research confirmed that the hypothesis is positively supported through self-efficacy that makes the e-learning system useful. Fourth, there is a relationship between perceived ease of use and perceived usefulness (H7) $(\beta=$ 0.530577 and $t=5.753757)$ : the result of this research confirmed that the hypothesis is positively supported through perceived ease of use that makes the e-learning system useful. And there is a relationship between perceived ease of use and attitude toward use (H8) $(\beta=$ 0.289979 and $t=1.973729)$ : the result of this research confirmed that the hypothesis is positively supported through perceived ease of use that makes the e-learning system useful and easy thus, students' attitude to use it. Also, there is a relationship between perceived ease of use and actual use e-learning (H9) $(\beta=0.374401$ and $t=$ 2.393632): the result of this research confirmed that the hypothesis is positively supported through perceived ease of use that makes the e-learning system useful and easy; thus, students actually use the e-learning system for learning. Fifth, there is a relationship between perceived usefulness and attitude toward use (H10) $(\beta=0.330564$ and $t=2.035344)$ : the result of this research confirmed that the hypothesis is positively supported through perceived usefulness that makes the e-learning system useful thus, students attitude to use it. And, there is a relationship between perceived usefulness and attitude toward use $(\mathrm{H} 11)(\beta=0.422371$ and $t=2.923845)$ : the result of this research confirmed that the hypothesis is positively supported through perceived usefulness that makes the e-learning system useful thus, students actually use the e-learning system for learning. Finally, the relationship between attitude toward use and e-learning system during COVID-19 (H12) $(\beta=0.288759$ and $t=2.858943)$, the result of this research confirmed that hypothesis is positively supported through students' attitude toward the use that affects students' actual use of the e-learning system for learning. This is consistent with previous studies in the same field (Almanthari et al., 2020; Abbasi et al., 2020; Radha et al., 2020; Al-Rahmi et al., 2019b; Al-Rahmi et al., 2018b; Chu and Chu, 2010; Chen and Tseng, 2012; Raheem and Khan, 2020).

\section{DISCUSSIONS AND IMPLEMENTATIONS}

This research analyzed college students' understanding of the use, adoption, and acceptance of online learning during stay-at-home orders due to COVID-19. In order to explore variables forecasting the use of the e-learning system during the pandemic, a variant of the extended TAM was successfully used in this study to illustrate the mechanism perceived by university students of implementing the e-learning system during the pandemic. From the results, other researchers who are interested in doing research in the field of technology integration, particularly during pandemics such as COVID-19 and based on virtual-based studies among university students, can analyze and adapt the scale in the future. The tool helps to resolve the important contribution of the structural equation study for developing academic skills. The model is stated to be accurate and reliable through the material validity and measurement model. For the testing of their scale, previous studies used similar measurements (Ramírez-Correa et al., 2015; Al-Rahmi et al., 2018c; Moafa et al., 2018). Through the results of the research, it was revealed that facilitating condition, perceived control, and self-efficacy have a significant relationship with perceived usefulness and perceived ease of use and confirmed all the hypotheses of the current study. In addition, the results of the study showed that the students' attitude toward using the system has a significant relationship with the actual use of the e-learning system during the COVID-19 pandemic. It can be concluded that during the pandemic, the facilitating situation such as adequate facilities, good climate, and easy access to the Internet will make it easier for Saudi students to use the e-learning system. Usage of the e-learning system was also recorded at normal times to significantly predict perceived utility, perceived ease of use, and learning by students (Nikou and Economides, 2017; Muhaimin et al., 2019; Alyoussef et al., 2019). A significant relationship between facilitating condition, perceived control, self-efficacy, and perceived usefulness is positively associated with the perceived ease of use, which in turn affects the attitude of students toward use, which in turn affects the use of the e-learning system during the COVID-19 pandemic. The model was presented to show that the atmosphere and tools for using the e-learning system enhance the beneficial effects perceived by university students of the use of the e-learning system during 
the pandemic. The outcome contradicts a previous finding by Muhaimin et al. (2019) that found an insignificant predictive capacity to promote perceived utility for Web 2.0 integration conditions. The finding of this study stated that it substantially predicts perceived utility with regard to perceived ease of use; when the e-learning system is perceived to be user-friendly, respondents enhance their feelings during the COVID-19 pandemic toward the value of the instruments. This result was supported by related studies from previous researchers (Mohammadi, 2015; RamírezCorrea et al., 2015; Zhang et al., 2008). It is also stated that perceived ease of use has a close association with attitude; a shred of proof that the more students think the e-learning system is easy, the more during the pandemic they act against the use of the e-learning system. Buabeng-Andoh et al. (2019) confirmed this result through their meta-analysis research and Muhaimin et al. (2019) through their observational evidence. Furthermore, it was observed that the association between perceived usefulness and attitude to use was highly important. Other research works in the integration of the e-learning method have indicated that the perceived easy to use and perceived usefulness would be more likely to be improved as respondents consider that technology benefits instructional practices (Zhang et al., 2008; Ramírez-Correa et al., 2015; Nikou and Economides, 2017; Al-Rahmi et al., 2018a; Teo et al., 2019; ). In comparison, during the pandemic, the more attitude the participants had about the use of the e-learning method, the better the likelihood for them to learn using the tool. Some previous research has also identified a substantial association between attitudes toward the use of technology in education (Muhaimin et al., 2019; Alhussain et al., 2020). Finally, in forecasting the real use of the e-learning method during COVID-19, which was confirmed by results from Teo (2009); Zhang et al. (2008); Ramírez-Correa et al. (2015); AlRahmi et al. (2015b), the attitude to use was stated to be important. They also found that behavioral intent during teaching and learning processes was a primary indicator of the use of the e-learning method. The consistency of teaching materials of the e-learning method influences the learning of the students (Sun et al., 2008), and it is often important to encourage an effort to allow learning of students through the use of technology during pandemics such as COVID-19. In our study, the average level of a student learning through online learning was found to be strong, and during the pandemic, the attitudes of students to use were very optimistic toward online learning. According to our research, the lack of the student learning from both teachers and peers impacted students. In general, students consider the program a beneficial mechanism for online learning during the COVID-19 pandemic as it comes to the mindset of students regarding the application of the e-learning system platform. Our findings indicate that the technology adoption model may be strengthened by taking into account such external influences, such as the technological conditions provided by the universities, the technical conditions of the schools, the teaching style of the teachers, the technical skills of the teachers, and the learning of the students across the network. If the TAM model may explain the attitude of using e-learning systems in the sense in which the framework is used as a supplementary method for the conventional educational method, an updated model version could explain the attitude of using it during pandemics such as COVID-19 in the context of online learning. This article further shows that since the transition to online learning, students have used more platforms and online instructional resources than ever. The use of emergency e-learning system services, as Murphy (Murphy (2020)) stated, increased the awareness of technical resources among students.

\section{Conclusion and Future Research}

This analysis interprets university student viewpoints, which showed that during the COVID-19 pandemic, online learning was an influential and successful source of the e-learning system. According to the students, online learning is an engaging and productive source of learning for students that helps with simple administration and accessibility of distant learning along with less use of resources and time. The instructional content can easily be reached by learners regardless of the time limit. The TAM model has been extensively used to investigate the e-learning system in normal circumstances in higher education (Ramírez-Correa et al., 2015; Zhang et al., 2008; Alenazy et al., 2019). This bulk surveys have shown that e-learning programs have been adopted across countries across the globe. For different situations and environments, the assessment of variables influencing the use of the e-learning system during outbreaks such as COVID-19 should be introduced. Most TAM-based relationships were reported to be strongly associated by concentrating on the e-learning system of students during pandemic. Furthermore, this study relates to areas of access where not many students have sufficient technology services that are linked to promoting conditions, especially Internet access. The present study therefore enriches scholarly literature in understanding the state of distance learning during the closing of universities and schools' doors due to pandemics, an important guideline for future research. However, the adoption and use of the e-learning system by students is much more difficult and definitely inevitable than that of usual circumstances due to the closures of colleges and colleges. Therefore, to enhance the learning of students, it is necessary to maximize the investment of the e-learning system in higher education. Future researchers interested in doing related styles of analysis require funding for the findings of the analysis. As a result of an epidemic, stakeholders should brace more for distance learning. While this analysis presents the existence of statistical evidence, there are several drawbacks to this report. Respondents interested in this research are only from one university; thus, future studies need more respondents from different major backgrounds. However, during a pandemic like COVID-19, a few studies explored the use of the e-learning method.

\section{DATA AVAILABILITY STATEMENT}

The original contributions presented in the study are included in the article/Supplementary Material, further inquiries can be directed to the corresponding author.

\section{AUTHOR CONTRIBUTIONS}

The author confirms being the sole contributor of this work and has approved it for publication. 


\section{REFERENCES}

Abad, N. S., and Sheldon, K. M. (2008). Parental Autonomy Support and Ethnic Culture Identification Among Second-Generation Immigrants. J. Fam. Psychol. 22 (4), 652-657. doi:10.1037/0893-3200.22.3.652

Abbasi, S., Ayoob, T., Malik, A., and Memon, S. I. (2020). Perceptions of Students Regarding E-Learning during Covid-19 at a Private Medical College. Pak J. Med. Sci. 36 (COVID19-S4), S57. doi:10.12669/pjms.36.covid19-s4.2766

Abdullah, F., Ward, R., and Ahmed, E. (2016). Investigating the Influence of the Most Commonly Used External Variables of TAM on Students' Perceived Ease of Use (PEOU) and Perceived Usefulness (PU) of E-Portfolios. Comput. Hum. Behav. 63, 75-90. doi:10.1016/j.chb.2016.05.014

Abuhassna, H., Al-Rahmi, W. M., Yahya, N., Zakaria, M. A. Z. M., Kosnin, A. B. M., and Darwish, M. (2020). Development of a New Model on Utilizing Online Learning Platforms to Improve Students' Academic Achievements and Satisfaction. Int. J. Educ. Technology Higher Education 17 (1), 1-23. doi:10. 1186/s41239-020-00216-z

Al-Maatouk, Q., Othman, M. S., Aldraiweesh, A., Alturki, U., Al-Rahmi, W. M., and Aljeraiwi, A. A. (2020). Task-technology Fit and Technology Acceptance Model Application to Structure and Evaluate the Adoption of Social media in Academia. IEEE Access 8, 78427-78440. doi:10.1109/access.2020.2990420

Al-Rahmi, W., Aldraiweesh, A., Yahaya, N., and Bin Kamin, Y. (2018b). Massive Open Online Courses (MOOCS): Systematic Literature Review in Malaysian Higher Education. Ijet 7 (4), 2197-2202. doi:10.14419/ijet.v7i4.15156

Al-Rahmi, W. M., Alias, N., Othman, M. S., Alzahrani, A. I., Alfarraj, O., Saged, A. A., et al. (2018c). Use of E-Learning by university Students in Malaysian Higher Educational Institutions: A Case in Universiti Teknologi Malaysia. IEEE Access 6, 14268-14276. doi:10.1109/access.2018.2802325

Al-Rahmi, W. M., Alias, N., Othman, M. S., Marin, V. I., and Tur, G. (2018a). A Model of Factors Affecting Learning Performance through the Use of Social media in Malaysian Higher Education. Comput. Education 121, 59-72. doi:10. 1016/j.compedu.2018.02.010

Al-Rahmi, W. M., Alzahrani, A. I., Yahaya, N., Alalwan, N., and Kamin, Y. B. (2020a). Digital Communication: Information and Communication Technology (ICT) Usage for Education Sustainability. Sustainability 12 (12), 5052. doi:10.3390/su12125052

Al-Rahmi, W., Othman, M. S., and Yusuf, L. M. (2015a). The Role of Social media for Collaborative Learning to Improve Academic Performance of Students and Researchers in Malaysian Higher Education. Int. Rev. Res. Open Distributed Learn. 16 (4). doi:10.19173/irrodl.v16i4.2326

Al-rahmi, W. M., Othman, M. S., and Yusuf, L. M. (2015b). Using Social media for Research: The Role of Interactivity, Collaborative Learning, and Engagement on the Performance of Students in Malaysian post-secondary Institutes. Mediterr. J. Soc. Sci. 6 (5), 536. doi:10.5901/mjss.2015.v6n5s2p536

Al-Rahmi, W. M., Yahaya, N., Aldraiweesh, A. A., Alamri, M. M., Aljarboa, N. A., Alturki, U., et al. (2019a). Integrating Technology Acceptance Model with Innovation Diffusion Theory: An Empirical Investigation on Students' Intention to Use E-Learning Systems. IEEE Access 7, 26797-26809. doi:10. $1109 /$ access.2019.2899368

Al-Rahmi, W. M., Yahaya, N., Aldraiweesh, A. A., Alturki, U., Alamri, M., Bin Saud, M. S., et al. (2019b). Big Data Adoption and Knowledge Management Sharing: An Empirical Investigation on Their Adoption and Sustainability as a Purpose of Education. IEEE Access 7, 47245-47258. doi:10.1109/access.2019. 2906668

Al-Rahmi, W. M., Yahaya, N., Alturki, U., Alrobai, A., Aldraiweesh, A. A., Omar Alsayed, A., et al. (2020b). Social media - Based Collaborative Learning: the Effect on Learning success with the Moderating Role of Cyberstalking and Cyberbullying. Interactive Learn. Environments, 1-14. doi:10.1080/10494820. 2020.1728342

Alalwan, N., Al-Rahmi, W. M., Alfarraj, O., Alzahrani, A., Yahaya, N., and AlRahmi, A. M. (2019). Integrated Three Theories to Develop a Model of Factors Affecting Students' Academic Performance in Higher Education. Ieee Access 7, 98725-98742. doi:10.1109/access.2019.2928142

Alamri, M. M., Almaiah, M. A., and Al-Rahmi, W. M. (2020). The Role of Compatibility and Task-Technology Fit (TTF): On Social Networking Applications (SNAs) Usage as Sustainability in Higher Education. IEEE Access 8, 161668-161681. doi:10.1109/access.2020.3021944
Alenazy, W. M., Mugahed Al-Rahmi, W., and Khan, M. S. (2019). Validation of TAM Model on Social media Use for Collaborative Learning to Enhance Collaborative Authoring. Ieee Access 7, 71550-71562. doi:10.1109/access. 2019.2920242

Alhussain, T., Al-Rahmi, W. M., and Othman, M. S. (2020). Students' Perceptions of Social Networks Platforms Use in Higher Education: A Qualitative Research. Int. J. Adv. Trends Computer Sci. Eng. 9 (3). doi:10.30534/ijatcse/2020/16932020

Allo, M. D. (2020). Is the Online Learning Good in the Midst of Covid-19 Pandemic? the Case of EFL Learners. Jurnal Sinestesia 10 (1), 1-10. doi:10. $1109 /$ access.2018.2866525

Almanthari, A., Maulina, S., and Bruce, S. (2020). Secondary School Mathematics Teachers' Views on E-Learning Implementation Barriers during the COVID-19 Pandemic: the Case of Indonesia. Eurasia J. Math. Sci. Technology Education 16 (7), em1860. doi:10.29333/ejmste/8240

Alyoussef, I. Y., Alamri, M. M., and Al-Rahmi, W. M. (2019). Social media Use (SMU) for Teaching and Learning in Saudi Arabia. Int. J. Recent Technol. Eng.(IJRTE) 8, 942-946. doi:10.35940/ijrte.D7569.118419

Bandura, A. (1986). Social Foundations of Thought and Action. Englewood Cliffs, NJ: Prentice-Hall.

Bandura, A. (1977). Self-efficacy: toward a Unifying Theory of Behavioral Change. Psychol. Rev. 84, 191-215. doi:10.1037/0033-295x.84.2.191

Bandura, A., and Wood, R. (1989). Effect of Perceived Controllability and Performance Standards on Self-Regulation of Complex Decision Making. J. Personal. Soc. Psychol. 56 (5), 805-814. doi:10.1037/0022-3514.56.5.805

Bonneville-Roussy, A., Vallerand, R. J., and Bouffard, T. (2013). The Roles of Autonomy Support and Harmonious and Obsessive Passions in Educational Persistence. Learn. Individual Differences 24, 22-31. doi:10.1016/j.lindif.2012.12.015

Buabeng-Andoh, C., Yaokumah, W., and Tarhini, A. (2019). Investigating Students' Intentions to Use ICT: A Comparison of Theoretical Models. Educ. Inf. Technol. 24 (1), 643-660. doi:10.1007/s10639-018-9796-1

Chen, H.-R., and Tseng, H.-F. (2012). Factors that Influence Acceptance of WebBased E-Learning Systems for the In-Service Education of Junior High School Teachers in Taiwan. Eval. Program Plann. 35 (3), 398-406. doi:10.1016/j. evalprogplan.2011.11.007

Cheng, Y. M. (2012). Effects of Quality Antecedents on E-learning Acceptance. Internet Research 22. doi:10.1108/10662241211235699

Chu, R. J., and Chu, A. Z. (2010). Multi-level Analysis of Peer Support, Internet Self-Efficacy and E-Learning Outcomes - the Contextual Effects of Collectivism and Group Potency. Comput. Education 55 (1), 145-154. doi:10.1016/j. compedu.2009.12.011

Clark, R. C., and Mayer, R. E. (2016). E-learning and the Science of Instruction: Proven Guidelines for Consumers and Designers of Multimedia Learning. John Wiley \& Sons.

Connell, J. P. (1985). A New Multidimensional Measure of Children's Perceptions of Control. Child. Development 56 (4), 1018-1041. doi:10.2307/1130113

Davis, F. D. (1989). Perceived Usefulness, Perceived Ease of Use, and User Acceptance of Information Technology. MIS Q. 13, 319-340. doi:10.2307/249008

DeCharms, R. (1976). Enhancing Motivation: Change in the Classroom. New York: Irvington.

Demir, M., Şimşek, Ö. F., and Procsal, A. D. (2013). I Am So Happy ‘Cause My Best Friend Makes Me Feel Unique: Friendship, Personal Sense of Uniqueness and Happiness. J. Happiness Stud. 14 (4), 1201-1224. doi:10.1007/s10902-0129376-9

Eshel, Y. (1991). Authority Structure, Classroom Openness and Student Outcomes. Educ. Psychol. 11 (2), 129-141. doi:10.1080/0144341910110202

Favale, T., Soro, F., Trevisan, M., Drago, I., and Mellia, M. (2020). Campus Traffic and E-Learning during COVID-19 Pandemic. Computer Networks 176, 107290. doi:10.1016/j.comnet.2020.107290

Fischer, H., Heise, L., Heinz, M., Moebius, K., and Koehler, T. (2014). “E-learning Trends and Hypes in Academic Teaching. Methodology and Findings of a Trend Study," in Proceedings of the International Association for Development of the Information Society (IADIS) International Conference on Cognition and Exploratory Learning in the Digital Age (CELDA), Porto, Portugal, 25-27 October 2014, 63-69.

Guarner, J. (2020). Three Emerging Coronaviruses in Two Decades. Am. J. Clin. Pathol. 153 (4), 420-421. doi:10.1093/ajcp/aqaa029

Habibi, A., Yusop, F. D., and Razak, R. A. (2020). The Role of TPACK in Affecting Pre-service Language Teachers' ICT Integration during Teaching Practices: 
Indonesian Context. Educ. Inf. Technol. 25 (3), 1929-1949. doi:10.1007/s10639019-10040-2

Hair, J. F., Risher, J. J., Sarstedt, M., and Ringle, C. M. (2019). When to Use and How to Report the Results of PLS-SEM. Ebr 31 (1), 2-24. doi:10.1108/ebr-11-2018-0203

Huang, C., Wang, Y., Li, X., Ren, L., Zhao, J., Hu, Y., et al. (2020). Clinical Features of Patients Infected with 2019 Novel Coronavirus in Wuhan, China. The Lancet 395 (10223), 497-506. doi:10.1016/s0140-6736(20)30183-5

Illeris, K. (2003). Towards a Contemporary and Comprehensive Theory of Learning. Int. J. Lifelong Education 22 (4), 396-406. doi:10.1080/ 02601370304837

Islam, A. K. M. N. (2013). Investigating E-Learning System Usage Outcomes in the university Context. Comput. Education 69, 387-399. doi:10.1016/j.compedu. 2013.07.037

Kerres, M. (2020). Against All Odds: Education in Germany Coping with Covid19. Postdigit Sci. Educ. 2 (3), 690-694. doi:10.1007/s42438-020-00130-7

Lai, C.-C., Shih, T.-P., Ko, W.-C., Tang, H.-J., and Hsueh, P.-R. (2020). Severe Acute Respiratory Syndrome Coronavirus 2 (SARS-CoV-2) and Coronavirus Disease-2019 (COVID-19): The Epidemic and the Challenges. Int. J. Antimicrob. Agents 55 (3), 1-9. doi:10.1016/j.ijantimicag.2020.105924

Liaw, S.-S., and Huang, H.-M. (2013). Perceived Satisfaction, Perceived Usefulness and Interactive Learning Environments as Predictors to Self-Regulation in E-Learning Environments. Comput. Education 60, 14-24. doi:10.1016/j. compedu.2012.07.015

Liaw, S. S., and Huang, H. M. (2014). Investigating Learner Attitudes toward E-Books as Learning Tools: Based on the Activity Theory Approach. Interactive Learn. Environments 24 (3). doi:10.1080/10494820.2014.915416

Megahed, M., and Mohammed, A. (2020). Modeling Adaptive E-Learning Environment Using Facial Expressions and Fuzzy Logic. Expert Syst. Appl. 157, 113460. doi:10.1016/j.eswa.2020.113460

Moafa, F. A., Ahmad, K., Al-Rahmi, W. M., Yahaya, N., Kamin, Y. B., and Alamri, M. M. (2018). Develop a Model to Measure the Ethical Effects of Students through Social media Use. IEEE Access 6, 56685-56699.

Mohammadi, H. (2015). Investigating Users' Perspectives on E-Learning: An Integration of TAM and IS success Model. Comput. Hum. Behav. 45, 359-374. doi:10.1016/j.chb.2014.07.044

Muhaimin, M., Habibi, A., Mukminin, A., Pratama, R., Asrial, A., and Hera, H. (2019). Predicting Factors Affecting Intention to Use Web 2.0 in Learning: Evidence from Science Education. Jbse 18 (4), 595-606. doi:10.33225/jbse/19.18.595

Murphy, M. P. A. (2020). COVID-19 and Emergency eLearning: Consequences of the Securitization of Higher Education for post-pandemic Pedagogy. Contemp. Security Pol. 41 (3), 492-505. doi:10.1080/13523260.2020.1761749

Nikou, S. A., and Economides, A. A. (2017). Mobile-based Assessment: Investigating the Factors that Influence Behavioral Intention to Use. Comput. Education 109, 56-73. doi:10.1016/j.compedu.2017.02.005

Omar, A., Kalulu, D., and Alijani, G. S. (2011). Management of Innovative E-Learning Environments. Acad. Educ. Leadersh. J. 15 (3), 37.

Peral, B. P., Gaitán, J. A., and Ramón-Jerónimo, M. Á. (2014). Technology Acceptance Model y mayores: ¿la educación y la actividad laboral desarrollada son variables moderadoras?. Revista Española de Investigación de Marketing ESIC 18 (1), 43-56. doi:10.1016/s11381442(14)60005-x

Pikkarainen, T., Pikkarainen, K., Karjaluoto, H., and Pahnila, S. (2004). Consumer Acceptance of Online Banking: An Extension of the Technology Acceptance Model. Internet Res. 14 (3), 224-235. doi:10.1108/10662240410542652

Popovici, A., and Mironov, C. (2015). Students' Perception on Using eLearning Technologies. Proced. - Soc. Behav. Sci. 180, 1514-1519. doi:10.1016/j.sbspro. 2015.02.300

Radha, R., Mahalakshmi, K., Kumar, V. S., and Saravanakumar, A. R. (2020). E-learning during Lockdown of Covid-19 Pandemic: A Global Perspective. Int. J. Control automation 13 (4), 1088-1099.

Raheem, B. R., and Khan, M. A. (2020). The Role of E-Learning in COVID-19 Crisis. Int. J. Creat. Res. Thought (Ijcrt) 8 (3), 3135-3138.

Rahimi, E., van den Berg, J., and Veen, W. (2015). Facilitating Student-Driven Constructing of Learning Environments Using Web 2.0 Personal Learning
Environments. Comput. Education 81, 235-246. doi:10.1016/j.compedu.2014. 10.012

Ramírez-Correa, P. E., Arenas-Gaitán, J., and Rondán-Cataluña, F. J. (2015). Gender and Acceptance of E-Learning: a Multi-Group Analysis Based on a Structural Equation Model Among College Students in Chile and Spain. PloS one 10 (10), e0140460. doi:10.1371/journal.pone. 0140460

Ratna, P. A., and Mehra, S. (2015). Exploring the Acceptance for E-Learning Using Technology Acceptance Model Among university Students in India. Ijpmb 5 (2), 194-210. doi:10.1504/ijpmb.2015.068667

Sekaran, U., and Bougie, R. (2016). Research Methods for Business: A Skill Building Approach. John Wiley \& Sons.

Shi, D., Wang, T., Xing, H., and Xu, H. (2020). A Learning Path Recommendation Model Based on a Multidimensional Knowledge Graph Framework for E-Learning. Knowledge-Based Syst. 195, 105618. doi:10.1016/j.knosys.2020. 105618

Simon, R. A., Aulls, M. W., Dedic, H., Hubbard, K., and Hall, N. (2015). Exploring Student Persistence in STEM Programs: A Motivational Model. Can. J. Education 38 (1), 1-27.

Sobaih, A. E. E., Hasanein, A. M., and Abu Elnasr, A. E. (2020). Responses to COVID-19 in Higher Education: Social media Usage for Sustaining Formal Academic Communication in Developing Countries. Sustainability 12 (16), 6520. doi: $10.3390 / \mathrm{su} 12166520$

Sun, P.-C., Tsai, R. J., Finger, G., Chen, Y.-Y., and Yeh, D. (2008). What Drives a Successful E-Learning? an Empirical Investigation of the Critical Factors Influencing Learner Satisfaction. Comput. Education 50 (4), 1183-1202. doi:10.1016/j.compedu.2006.11.007

Taherdoost, H. (2016). Sampling Methods in Research Methodology; How to Choose a Sampling Technique for Research. How to Choose a Sampling Technique for Research. (April 10, 2016). Available at: https://ssrn.com/ abstract $=3205035$.

Teo, T. (2009). Is There an Attitude Problem? Reconsidering the Role of Attitude in the TAM. Br. J. Educ. Technol. 40 (6), 1139-1141. doi:10.1111/j.1467-8535. 2008.00913.x

Teo, T., Sang, G., Mei, B., and Hoi, C. K. W. (2019). Investigating Pre-service Teachers' Acceptance of Web 2.0 Technologies in Their Future Teaching: a Chinese Perspective. Interactive Learn. environments 27 (4), 530-546. doi:10. 1080/10494820.2018.1489290

UNESCO (2020). UNESCO Covid-19 Educational Disruption and Response. Available at: https://en.unesco.org/covid19/educationresponse (Accessed November 11, 2020).

Vankatesh, V., and Davis, F. D. (1996). A Model of the Antecedents of Perceived Ease of Use: Development and Test. Decis. Sci. 27 (3), 451-481.

Venkatesh, V. (2000). Determinants of Perceived Ease of Use: Integrating Control, Intrinsic Motivation, and Emotion into the Technology Acceptance Model. Inf. Syst. Res. 11 (4), 342-365. doi:10.1287/isre.11.4.342.11872

Wang, C. J., Ng, C. Y., and Brook, R. H. (2020). Response to COVID-19 in Taiwan. Jama 323 (14), 1341-1342. doi:10.1001/jama.2020.3151

World Health Organization (2020). WHO Coronavirus Disease (COVID-19) Dashboard. Available at: https://covid19.who.int/(Accessed November 11, 2020).

Zhang, S., Zhao, J., and Tan, W. (2008). Extending TAM for Online Learning Systems: An Intrinsic Motivation Perspective. Tinshhua Sci. Technol. 13 (3), 312-317. doi:10.1016/s1007-0214(08)70050-6

Conflict of Interest: The author declares that the research was conducted in the absence of any commercial or financial relationships that could be construed as a potential conflict of interest.

Copyright $\odot 2021$ Alyoussef. This is an open-access article distributed under the terms of the Creative Commons Attribution License (CC BY). The use, distribution or reproduction in other forums is permitted, provided the original author(s) and the copyright owner(s) are credited and that the original publication in this journal is cited, in accordance with accepted academic practice. No use, distribution or reproduction is permitted which does not comply with these terms. 